NBER WORKING PAPER SERIES

\title{
UNEMPLOYMENT EFFECTS OF MILITARY SPENDING: EVIDENCE FROM A PANEL OF STATES
}

Mark Hooker

Michael Knetter

Working Paper No. 4889

\author{
NATIONAL BUREAU OF ECONOMIC RESEARCH \\ 1050 Massachusetts Avenue \\ Cambridge, MA 02138 \\ October 1994
}

\begin{abstract}
We would like to thank Bill Enumons, Andrew Oswald, and members of the Darmouth economics department's junior lunch seminar for helpful comments and discussion. We also thank Michael Berger of the Department of Defense for assistance with the data. This paper is part of NBER's research programs in Economic Fluctuations and Labor Studies. Any opinions expressed are those of the authors and not those of the National Bureau of Economic Research.

(C) 1994 by Mark Hooker and Michael Knetter. All rights reserved. Short sections of text, not to exceed two paragraphs, may be quoted without explicit permission provided that full credit, including $\odot$ notice, is given to the source.
\end{abstract}




\title{
UNEMPLOYMENT EFFECTS OF MILITARY SPENDING: EVIDENCE FROM A PANEL OF STATES
}

\begin{abstract}
We use data on a panel of states over a 30 year sample to estimate the response of unemployment to military procurement spending. The state panel provides greater variation in both variables and permits us to examine whether responses to procurement spending shocks vary across states. Our main finding is that changes in procurement spending significantly affect unemployment in states heavily dependent on the military sector and subject to large such changes, and that accounting for this variation in responses across states adds approximately $40 \%$ to the estimated aggregate unemployment impact of the current drawdown.
\end{abstract}

Mark Hooker

Department of Economics

Dartmouth College

Hanover, NH 03755
Michael Knetter

Department of Economics

Dartmouth College

Hanover, NH 03755

and NBER 


\section{Unemployment Effects of Military Spending: \\ Evidence from a Panel of States* \\ Mark Hooker and Michael Knetter}

The ongoing reductions in military spending have revived policy interest in the relationship between military spending and aggregate fluctuations. ${ }^{1}$ A variety of conventional macroeconomic models suggest that changes in military spending affect economic activity, at least in the short run. The mechanism by which defense purchases affect output varies across models. Military spending affects output through shifts in aggregate demand in models in the Keynesian tradition. Other models emphasize the reallocation of resources that occurs when spending changes across sectors of the economy and the consequent loss of output and increase in measured unemployment during the transition period. ${ }^{2}$

The studies which accompanied plans to downsize the military in recent years generally concluded that the proposed reduction in military spending, which amounts to a 3 percentage point reduction in its share of GDP over a 10-year period, would have relatively minor effects on the mactoeconomy. Simulation results from macroeconometric models suggest, for example, that the planned drawdown will reduce annual output growth by about 0.25 to 0.50 percentage points over the 1993 to 1995 period. ${ }^{3}$ Okun's Law would thus imply a contribution to unemployment on the order of one or two tenths of a percentage point per year. Consistent with such a small impact, Shea (1992) finds that military spending is not a statistically significant determinant of output in any 2-digit

\footnotetext{
- We would like to thank Bill Emmons, Andrew Oswald, and members of the Darumouth economics department's junior lunch seminar for helpful commments and discussion. We also thank Michael Berger of the Department of Defense for assistance with the data.

1 A number of studies have emerged from think tanks, such as the Defense Budget Project and the Economic Policy Institute, government commissions, the Congressional Budget Office, as well as acadernics.

2 Lilien's (1982) investigation of the role of sectoral shifts in aggregate unemployment started a large literature on this topic.

${ }^{3}$ Such estimates appear in the $\mathrm{CBO}$ analysis and the report by the Defense Conversion Commission.
} 
manufacturing industry.

Other empirical observations, however, suggest that military spending changes have had large effects on the economy. Defense drawdowns associated with the conflicts in Korea and Vietnam have tended to coincide with downturns in the overall economy. ${ }^{4}$ Figure 1 shows that the Korean buildup was associated with a decline in unemployment of about 3 percentage points, while the subsequent drawdown was associated with a rise in unemployment that was nearly as large. Similarly, the Vietnam buildup that occurred during the Johnson Administration was associated with declining unemployment, while unemployment rates rose soon aftet spending on the Vietnam conflict fell.

Furthermore, the geographic distribution of unemployment increases in the recent recession seems to be highly correlated with the distribution of defense spending. Four of the states most heavily dependent on defense purchases-Connecticut, Virginia, Massachusetts, and California-experienced a combined increase in their unemployment rates that was over two-and-one-half times the increase in the rest of the United States in the four year period ending in September 1992.5 Of the major manufacturing sectors in the economy, the largest decline in employment in the 1989-1992 period occurred in transportation equipment, with nearly two-thirds of that loss concentrated in aerospace (aircraft and guided missiles). This leads us to believe that the distributional effects of defense spending are important and that macroeconometric simulations based only on aggregate data may be misleading.

Overall, there appears to be somewhat of a puzzle surrounding the true impact of defense spending on short run fluctuations in the economy. Macroeconometric models seem to agree that military spending changes of the magnitude we have seen since the

\footnotetext{
${ }^{4}$ There was a sharp fall in output and rise in unemployment following World War I; more modest effects were associated with the spending reductions near the end of the Korean and Vietnam conflicts. It should be noted, however, that changes in defense spending as a share of the economy were larger in these previous episodes than the current reductions. The Vietnam drawdown entailed a decline of 4.8 percentage points in the share of GDP devoted to defense over a 10-year period. This compares with a projected decline of 2.9 percentage points over 11 years in the current environment. See the report of the Defense Conversion Commission.

5 See the 1993 Economic Report of the President, pp. 89-90.
} 
World War II drawdown are too small to have big effects on the economy. Nonetheless, past defense drawdowns appear to have coincided with national recessions and the regional distribution of unemployment during the most recent recession is consistent with the view that ongoing or impending defense spending reductions played an important role. This paper will attempt to characterize the empirical relationship between military spending and unemployment by examining the behavior of unemployment and procurement spending by state since the early $1960 \mathrm{~s}$. The panel of states provides us with considerably more variation than exists in the aggregate time series. Our focus on procurement spending is a consequence of our lack of state-specific data on other forms of military spending.

Procurement spending accounts for less than $50 \%$ of the current drawdown and approximately $30 \%$ of total military spending.

We begin by discussing the empirical framework and data used to study the behavior of state unemployment rates. We then estimate reduced-form models of state unemployment rates and test a variety of restrictions in an attempt to identify key features of the relationship between procurement spending and unemployment rates. Our main finding is that changes in procurement spending significantly affect unemployment in those states most dependent on the military sector, and that allowing for variation across states in the response of unemployment to procurement spending adds approximately $40 \%$ to the estimated aggregate unemployment impact of the current drawdown. The paper concludes with some discussion of the implications of our results and possible mechanisms that might generate them.

\section{The Empirical Model}

The main objective of this paper is to estimate the impact of military spending on unemployment, using variation across states and over time to identify responses. One possible approach to the problem would be to estimate a structural model of labor market equilibrium, which would include determination of employment, labor force participation, 
and wage rates, as well as unemployment for each state. However, labor supply, labor demand, and labor market equilibrium are extremely difficult to model empirically. This is particularly true given that our sample must cover a thirty-year period in order to capture just two big swings in defense procurement. Thus, we estimate a system of reduced-form unemployment equations for the fifty states plus the District of Columbia.

The specification we estimate is motivated by standard theories of labor market equilibrium, as surveyed in Nickell (1990). We take the view that each state has a long-run equilibrium level of unemployment which will depend on minimum wages, environmental and labor market regulations, industry mix, unemployment benefits, and other possibly state-specific factors, but that unemployment deviates from long-run equilibrium due to various shocks, including changes in military procurement spending. The response of unemployment to shocks will be allowed to vary across states to some degree.

We follow the approach of Marston (1985) and more recently Davis, Loungani, and Mahidhara (1992) in specifying our equations for state unemployment rates. Marston uses an error components model to decompose variation in state unemployment rates into time and state effects. The state-specific effects capture institutional features that are relatively constant over time but vary across states, giving rise to different long-run equilibrium rates of unemployment. The time effects capture the impact of factors common to all states that vary over time, such as demographic trends and aggregate demand and supply disturbances, many of which may be unmeasurable. 6

In addition to the fixed effects, we consider other possible sources of state-specific variation in unemployment rates in order to reduce omitted variables bias in our escimates of the response of unemployment to military spending. ${ }^{7}$ Unfortunately, most shocks to regional activity are difficult to measure. Two potential shocks we can measure are oil

\footnotetext{
6 Among the dislurbances captured will be the common effects of fluctuations in defense spending across states.

7 Of course one of the main reasons why military spending has been used as an instrumental variable in macroeconometric research (e.g. Hall (1988) and Ramey (1989)) is that it is driven largely by noneconomic factors, making it unlikely that it would have systematic correlation with other driving forces.
} 
prices and exchange rates. Oswald (1994) summarizes evidence that real oil prices are an important determinant of unemployment rates for the industrialized countries. Carruth, Hooker, and Oswald (1994) find that unemployment in Great Britain and Canada is positively correlated with real oil prices. Their finding suggests that oil price changes do not merely cause labor reallocation and search unemployment, since decreases in the price of oil are associated with declines in the rate of unemployment. Earlier, Hamilton (1983) found that oil price shocks appeared to be associated with all but one post-WWII recessions in the United States. The experience of the mid-1980s in the United States suggests that real exchange rate fluctuations may also have important differential impacts on regional unemployment due to state variation in exposure to international competition.

Research on state employment patterns has recently used an industry-mix variable, proposed by Bartik (1991), to control for the share of employment changes that can be associated with industry-specific shocks. ${ }^{8}$ Since industry employment growth is closely related to industry unemployment, this variable would also be a good proxy for the effect of industry shocks on state unemployment rates. Since the Bartik variable is available only from 1970-1989 and the rest of our data spans 1963-92, we perform most of our analysis without it, but examine its impact on our estimated model over this sub period.

We begin by estimating the basic model given by:

$$
U_{i t}=\Theta_{t}+\Lambda_{i}+\alpha_{i} H D B K_{i t}+\sum_{k=1}^{K} \rho_{k} U_{i, t-k}+\sum_{j=0}^{f} \beta_{j} M I L_{i, t-j}+\varepsilon_{i t}
$$

where $U$ denotes the unemployment rate, HDBK denotes the dummy variable for the source of unemployment data (explained in detail below), MIL denotes real military contracts per capita, $\Theta_{t}$ and $\Lambda_{i}$ represent time and state effects, respectively, and $i$ and $t$ index states and time periods. ${ }^{9}$ The error term, $\varepsilon_{i r}$, captures the influence of unmodelled

8 See, for example, Davis, et al, (1992) and Blanchard and Katz (1992).

9 A full set of time and state effects is not identified; we normalize by leaving out the first year-dummy. 
factors on the state unemployment rates, which are assumed to be independent and identically distributed.

The state fixed effects allow the equilibrium unemployment rates to differ actoss states and the time fixed effects allow for a common changes in the equilibrium rates (due to, say, Federal environmental policy changes) or disequilibrium deviations (e.g. from Federal tax changes) over time. The lagged unemployment term allows for persistent deviations of unemployment from its long-run equilibrium rate, without taking a stand on what the sources of persistence are. Deviations from long-run equilibrium may be persistent either because some shocks are serially correlated or the labor market equilibrates slowly. We assume that the dynamics of unemployment around its long-run equilibrium are the same for all states (i.e., the $\rho$ 's are common across states). Lags of procurement contracts are included because contract work may be spread over several years and the impact on the labor market may be delayed. As it is written, this equation suggests that procurement spending is a determinant of the long-run equilibrium unemployment rate for each state. Almost all theories of labor markets would imply instead that changes in procurement spending cause temporary departures from long-run equilibrium unemployment. We will test whether the data are consistent with this view.

\section{Data}

Our unemployment data for each state cover the 1963-1992 period. We use CPS estimates to the maximum extent possible, but for each state there is a transition year between 1970 and 1976 in which data change from BLS Handbook method estimates to CPS estimates. The BLS Handbook series is constructed from data on payroll, unemployment insurance, and other work force records that are kept by state employment security agencies. ${ }^{10}$ Since the CPS-based estimates are of ten quite different from the

10 These calculations are available in the Manpower Repon senies. CPS-based estimates of the unemploymenl rates are available beginning in 1970 for some large states, and in either 1973 or 1976 for
the remaining states. 
handbook estimates in those years where overlap exists, we introduce a dummy variable (HDBK) to capture the level-shift in unemployment rates associated with transition from handbook to CPS-based rates. The coefficients on these dummies are allowed to vary by state, since the underlying factors which cause the two series to diverge are likely to vary across states. ${ }^{11}$

Our military spending variable is real military contract awards per capita for each of the 50 states and the District of Columbia. The raw data on contracts come from the DD 350 database, which consists of all prime contracts in excess of $\$ 25,000$ awarded by the Department of Defense. ${ }^{12}$ Contracts are allocated across states according to the principle place of performance. ${ }^{13}$ Contracts vary in their length, or spend-out rates, which is one reason why we include a number of lags in estimation. There are a few negative contract values, which occur when more contracts are canceled than extended to a state in a particular year. State contract data are deflated by the GDP deflator and the state population. This has the effect of scaling the magnitude of the real shock to the size of the affected economy.

Conflicting evidence on the economic importance of military spending cited in the introduction may be partly a consequence of the small number of observations on aggregate fluctuations and military spending. The time series on unemployment and military purchases in the post-WWII period is probably too short to determine the appropriate specification with confidence and thus to provide conclusive evidence on the issue. These data on state unemployment rates and procurement expenditures provide us with not only a

11 The difference between the Handbook and CPS estimates varied by state quite substantially. The major reason for this is that the handbook method did not represent all types of employment equally well. Consequenily, states with different compositions of urban vs. rural or manufacturing vs. service sector employment were affected differently by the switch.

12 For part of our sample, the cutoff value for the database was $\$ 10,000$ per contract. Since prime contracts between $\$ 10,000$ and $\$ 25,000$ accounted for such a small fraction of total contract awards, we have ignored this definicional change in the series. In any case, it probably affected all states similarly, so would have little impact on our results. The exclusion of subcontracts may introduce some noise into the model, but there is no reason to expect any bias to result from the allocation of subcontracts across states.

${ }^{13}$ For example, a contract with an auto dealer in Arizona to deliver cars made in Michigan to a base in Arizona would show up as a contract for the state of Michigan, where most of the value was added. 
greater number of observations, but also a sample that exhibits greater variation. ${ }^{14}$

Figure 2 displays the average level of procurement spending per capita for the fifty states and the District of Columbia over the 1963-92 period. The chart reveals large differences in the economic importance of procurement spending actoss the states. Figure 3 shows that the time series behavior of procurement spending can differ substantially across states. In the 1980s, for example, contract awards fell much sooner in Connecticut and California than in Massachusetts. These differences in the timing of spending.changes across states provide us with additional variation to determine the role of procurement spending in shaping unemployment. Figure 3 also reveals the greater amplitude in statelevel vs. national procurement spending.

State-level relationships between unemployment and procurement spending are not perfectly analogous to the national relationship. The relatively greater opportunity for migration across states within a country than across countries leads us to expect that the relationship between unemployment and military spending is slightly weaker for states than it is for the nation as a whole. ${ }^{15}$ Thus, the state-level analysis will probably lead to an underestimate of the aggregate impact of procurement spending on unemployment.

\section{Estimation and Results}

We begin by estimating our basic model using OLS over the 1967-1992 period. Our first exercise is to estimate Equation (1) setting $J$ and $K$ equal to 4 , which allows for some dynamics without losing too many data points from our sample.

The results are presented in Table l. We report two pieces of state-specific information in the table: the state-specific fixed effects (and their $t$-statistics) and an $\mathrm{R}^{2}$

\footnotetext{
14 Another option would be to collect data for other countries, but we believe that spending per capita has been substanially greater in the United States, so that looking at state data is likely 10 yield greater variation across cross-sectional units and over time.

15 Topel (1986) and more recently Blanchard and Katz (1992) have shown that migration is an importanl factor in the labor market equilibration process across regions in the United Stutes. Undoubtedly, migration plays a much smaller role across countries due to stricter immigration policies.
} 
value calculated from the dependent variable and residuals for each state's observations. The table also reports the estimated time effects and the coefficients on lagged unemployment and real per capita procurement contracts.

Before discussing the response of unemployment to procurement, we note a few other features of the estimates. First, the state-specific effects are quite sensible. The low estimates are found in those states that are widely believed to have low natural rates of unemployment-Nebraska, New Hampshire, Kansas, and the Dakotas. Chronic highunemployment states, such as West Virginia, Michigan, and Alaska, have larger estimated state constants. The time effects change with overall economic fluctuations. The largest positive values occur in the recession years of 1975, 1980, 1982, 1983, and 1991. Whereas expansion years early in the sample tend to have negative estimated time effects, those in the later years are positive, suggesting a common upward trend in the natural rate of unemployment over our sample, which is consistent with most previous research on natural rates of unemployment. Finally, it appears that departures from the natural rate of unemployment have considerable persistence. The first lag of unemployment has an estimated coefficient of 0.86 and the lag polynomial has a dominant root of 0.70 .

The estimated responses of unemployment to contract awards, denoted with $\beta$ s, are in the lower left of the table. The contemporaneous contract awards have the largest impact $(-0.39)$ and the only statistically significant coefficient. The sum of all five coefficients (contemporaneous and four lags) equals -0.45 with a $t$-statistic of -1.96 . This implies that an increase in procurement contract awards per capita of a thousand 1987 dollars (moving from being one of the least to most procurement-intensive states) would permanently decrease state unemployment by about half a percentage point.

Equation (1) implies that military spending affects the long-run equilibrium unemployment rate. Almost all economic theories imply that military spending only affects deviations from equilibrium-i.e., the long-run equilibrium rate of unemployment in Massachusetts is unaffected by a permanent change in the level of military contract awards 
to that state. Since (1) nests specifications where changes in procurement spending affect equilibrium unemployment, we can test whether the data accept the restriction implied by theory.

Our next step is to test whether the basic model accepts the restriction that it is the change in contract awards that affects the rate of unemployment, and not the level. The results of this constrained specification are reported in Table 2 . Since the fixed effects and the lagged unemployment terms change very little with this change in specification, they are not reported again. The coefficients on the lagged values of the change in procurement contract awards (denoted by $\gamma$ s), however, are now all significant at the $10 \%$ level, and they and the contemporaneous coefficient are each estimated to be approximately -0.30 . Their sum equals -1.29 , ( $t$-statistic $=-2.66)$; the estimated impact on unemployment for the current drawdown is presented in Figure 5 and discussed below.

The p-value for the test of the restriction that the military contract variable should enter the specification in first-differences is equal to 0.05 , which is at the border of the rejection region for a standard test. However, our strong theoretical preference for the natural rate of unemployment to be invariant to the level of military spending, and the relatively large $t$-statistics on changes in procurement spending leads us to retain the restriction for our analysis. We note that while theoretically difficult to rationalize, the data express some preference for larger cumulative and more permanent effects of procurement spending on unemployment.

Our next modification to the basic specification is to examine how the response of unemployment to procurement spending varies across states. Initially we estimated a model in which $\gamma$ s were allowed to be state-specific. Unfortunately, time variation alone in this relatively short sample could not precisely estimate the state-specific $\gamma$ s. To alleviate this problem, we chose to group states into five quintiles, with Quintile 1 having the lowest levels of real procurement spending per capita and Quintile 5 having the highest. This grouping brings in cross sectional variation to help identify the coefficients, and 
allows us to analyze the hypothesis that state responses are heterogeneous based on the level of spending in that state.

Two mechanisms may be at work underlying this heterogeneity: furst, that dependence on the military sector makes a state more sensitive to a given-sized shock in that sector, and second, that states have different-sized responses to different-sized shocks (that is, that the procurement spending-unemployment relationship is nonlinearly increasing in spending changes). While we estimated with states grouped into quintiles by both of these measures (the quintile members are presented in Table 3, with the estimates in Table 4A and 4B), a distinction is difficult: states with high procurement spending are also ones with large changes (the correlation coefficient is 0.83 ). The sorting by level of procurement spending leads to more significance in individual coefficients and a significantly lower sum of squared residuals, so that is the specification we retain for most of the analysis.

The results of grouping the data in this way and allowing the military spending coefficient to vary across the groups is presented in Table 3. The response of unemployment to procurement spending is negajive for Quintiles 3, 4, and 5, but positive for Quintiles 1 and 2. The inverse relationship between procurement spending and unemployment is strongest in Quintile 5, where the sum of the contemporaneous and three lagged coefficients is -1.82 with a $t$-statistic of -3.13 . All of the individual coefficients in the 5 th quintile are significant at the $10 \%$ level and all but one at the $5 \%$ level. Two of the coefficients in Quintile 2 are positive and significant at the $10 \%$ level, but neither are significant at the $5 \%$ level.

In order to determine the economic significance of the differences in response across the quintiles, we simulated the model to estimate the impact of the current drawdown. For 1987-1992 we use the actual levels of procurement spending for each state; for 1993-97 we assume that procurement spending will fall an equal percentage each year to hit the projected 1997 spending amounts found in the 1993 Report of the Defense 
Conversion Commission. We also assume that the percentage reduction in spending after 1993 is equal across states. We assume that real per capita contracts remain constant after 1997.

Figures $4 \mathrm{~A}$ through $4 \mathrm{E}$ show the responses with $95 \%$ confidence intervals for the simulation. The first two quintiles show very small effects, with the point estimates actually indicating a decline in unemployment as a result of reductions in procurement contracts to those states. The three larger quintiles show adverse effects, with Quintile 5 showing a peak impact around 1995 of an additional 0.4 percentage points of unemployment associated with the procurement drawdown. In all cases, the effects vanish by 2003.

Another way to determine the economic significance of these differential responses across the state groupings is to compare the aggregate implications of the simulated drawdown under the assumption of identical responses across states versus the assumption that the response differs across the quintiles. This comparison is shown in Figure 5. With identical responses actoss states, the peak impact occurs in 1994 when procurement cutbacks contribute an estimated 0.11 percentage points to aggregate unemployment. When responses are allowed to differ by quintile, the aggregate implications are greater by about 40\%, with peak impacts in 1993 and 1995 of 0.15 percentage points.

The pattern of response across the quintiles suggests that states with a greater dependence on procurement spending have larger "elasticities" of unemployment with respect to procurement spending. In essence, the unemployment "multiplier" of procurement is larger in states with higher levels of spending. We interpret this as suggesting that the overall response of the economy to defense spending shocks is nonlinear: As the size of the shock increases, the multiplier effect of the shock becomes larger. This same phenomenon may have an aggregate time series analog: Periods of large changes in defense spending may also have proportionately larger unemployment responses. If the true relationship between unemployment and defense spending is non-linear, then 
simulation models that assume a linear relationship may underestimate the response of unemployment to large changes in defense spending.

In Table 5 we add two new controls to the basic model: oil prices and exchange rates. While oil price shocks may cause macroeconomic fluctuations that are captured in the fixed effects to some extent, these shocks have very different state impacts. Oil exporting states, such as Texas, typically expand when oil prices rise, while oil importing states whose industrial base is oil dependent, such as Ohio or Pennsylvania, will contract more than the national average during an oil price increase. Exchange rate fluctuations may also have differential impacts on state unemployment.

Table 5 shows that the allowing for state-specific responses to these shocks does not change the fundamental finding that procurement spending cuts tend to increase unemployment (in the model with state responses constrained to be equal) and that these increases are proportionately larger in states with a higher dependence on procurement spending (in the model where each quintile has a separate response). The responses to oil price and exchange rate changes are normalized around Nebraska. Texas, Wyoming, California, and Alaska are among the few states in which oil price increases have a smaller adverse impact (and potentially positive impact) than they do in Nebraska. Exchange rate changes seem to have their greatest impacts on the New England and Midwestern states, which is consistent with the findings reported by Singleton (1993).

Table 6 adds the Bartik variable to our model which is then estimated over the shorter sample period during which this series is available (1970-1989). This sample period misses some of the Vietnam buildup and drawdown and the latter part of the current drawdown. Table $6 \mathrm{~A}$ presents the results with the Bartik variable added to the basic model with quintiles, which is reported as Table $3 \mathrm{~A}$. The Bartik variable itself does not substantially weaken the negative relationship between unemployment and procurement spending in the 5th Quintile, although it does weaken the relationship for the other quintiles. The 5th Quintile is the only one to have a negative, statistically significant 
coefficient sum. When all states are constrained to have the same response, the results are nearly identical to those obtained in the basic model. Table 6B shows the results of adding the Bartik variable to the expanded model with oil prices and exchange rates, which is reported in Table 5. In this case, the constrained model shows a much weaker relationship, but the pattern across quintiles does hold up. Quintile 5 still shows a definite negative relationship between unemployment and procurement contract awards.

Overall, we find the evidence fairly convincing that procurement spending has important short run effects on aggregate unemployment. Our point estimates suggest that procurement cuts alone will add between one- and two-tenths of a percentage point to aggregate unemployment during 1994-95, based on the aggregate implications of the quintiles model. Since procurement cuts constitute only about half of the current drawdown in military spending, the current drawdown may contribute about two- to fourtenths of a percentage point to the national unemployment rate in these years.

The more robust finding is that states wilt. a higher average level of procurement spending show a greater unemployment multiplier associated with procurement spending. This pattern is evident in every specification. Only the ten most procurement-dependent states exhibit a statistically significant relationship between unemployment and procurement spending across all specifications. Nonetheless, the aggregate implications are greater when we recognize this concentration of impacts: Allowing for different unemployment responses to procurement across states also increased the aggregate sensitivity of unemployment to procurement spending (Figure 5).

One possible explanation for the observed heterogeneity in unemployment responses to procurement spending is that large regional shocks are exaggerated by regional character of banking in the United States. Any region-specific shock has a disproportionate influence on its banks, since their assets are not well diversified geographically-they hold too many loans to regional businesses, which in turn are collateralized by regional commercial and residential property. An adverse shock that is 
large enough to cause increases in business failures and declines in property values may create a "capital crunch," eroding bank capital and make lending to small businesses, which rely almost exclusively on local banks for credit, extremely difficult at precisely the time it may be needed most. Small businesses that have markets outside the region may be in a position to absorb labor at relatively low wage rates given the supply of idle workers in the wake of the original regional shock. Unfortunately, they may be unable to obtain credit from local banks if a capital crunch is underway.

Is there any evidence that defense drawdowns have been associated with capital crunches? We believe that the recent experience of regional property cycles is certainly supportive of our view. The recent boom and bust of property values in New England and Califomia seem to coincide fairly closely with the defense spending cycles over this same period. The growth and decline in defense spending was much more pronounced in New England and California than in the remainder of the nation (see Figure 3). The evidence that regional barking fueled the property boom is also quite striking. Peek and Rosengren (1992) report evidence that shows real estate assets on the balance sheets of New England commercial and savings banks rose by $242 \%$ from 1984 to 1989 , when property values appeared to peak. For the rest of the nation, growth in real estate assets among FDICinsured institutions was only $86 \%$. This burst of lending for real estate development made the New England banking system vulnerable to the rather sharp decline in property values that began around 1989. This tuming point in regional property values coincides nicely with an important intemational event: the fall of the Berlin Wall. Obviously, there were other important factors that were influencing bank balance sheets and property values at this time, but given the regional dependence on procurement spending, this shock may have been the key ingredient. This is something we plan to investigate in future reseanch.

\section{Conclusion}

This paper has examined the relationship between procurement spending and 
unemployment rates across states. There are two main findings. First is that military procurement spending does explain some of the variation in unemployment across states, and based on our estimates, the current cuts in procurement add about 0.15 percentage points to the national unemployment rate. The impact of the defense drawdown is likely to be twice as large, since procurement constitutes less than half of the spending reductions. Second, we find rather strong evidence in support of a non-linear relationship between these variables. In particular, procurement shocks cause proportionately larger increases in unemployment rates in those states with a large share of procurement spending. This may have important ramifications for forecasting the overall economic impact of defense spending reductions. In particular, models that assume a linear relationship between defense spending and short run economic activity are likely to underestimate the impact of a defense dawdou ri: on the economy. It also has ubvious ramifications for forecasting the regional economic impact of spending changes.

Finally, we conjecture that this non-linear relationship between procurement dependence and unemployment sensitivity is at least partly due to the lack of diversification of bank assets across regions. A large regional shock is likely to induce regional credit problems that magnify the impact of the original shock on other firms in the region. Restrictions on interstate banking may have the unintended consequence of increasing the amplitude of economic fluctuations. We will explore this possibility in future work. 


\section{References}

Bartik, Timothy J., Who Benefits from State and Local Economic Development Policies?, W.E. Upjohn Institute for Employment Research, Kalamazoo, MI.

Blanchard, Oliver, and Lawrence Katz, "Regional Evolutions," Brookings Papers on Economic Activity 1992:1, 1-61.

Carruth, Alan, Mark Hooker, and Andrew Oswald, "Unemployment, Oil Prices, and the Real Interest Rate: Evidence from Canada and the UK," forthcoming in Christofides, Grant, and Swidinsky, eds., Aspects of Labour Market Behaviour: Essays in Honour of John Varderkamn. University of Toronto Press, 1994.

Davis, Steve, Prakash Loungani, and Ramamohan Mahidhara, "Regional Unemployment Cycles," manuscript, November 1992.

Hall, Robert E., "The Relation Between Price and Marginal Cost in U.S. Industry," Journal of Political Economy, October 1988, 921-47.

Hamilton, James, "Oil and the Macroeconomy Since World War II," Journal of Political Economy, April 1983, 228-248.

Lilien, David, "Sectoral Shifts and Aggregate Unemployment," Journal of Political Economy, August 1982, 777-793.

Marston, Stephen, "Two Views of the Geographic Distribution of Unemployment," Quarterly Journal of Economics, February 1985, 57-79.

Nickell, Stephen, "Unemployment: A Survey," Economic Journal 100, 391-439.

Oswald, Andrew, "Four Pieces of the Unemployment Puzzle," unpublished manuscript, June 1994.

Peek, Joe, and Eric Rosengren, "The Capital Crunch in New England," New England Economic Review, May/June 1992, 21-31. 
Ramey, Valerie, "Inventories as Factors of Production and Economic Fluctuations," American Economic Review, June 1989, 338-354.

Shea, John, "The Input-Output Approach to Instrument Selection," Journal of Business and Economic Statistics, April 1993, 145-55.

Singleton, Christopher, "Industry Employment and the 1990-91 Recession," Monthly Labor Review, July 1993, 15-25.

Topel, Robert, "Local Labor Markets," Journal of Political Economy 94, 1986, S111S143.

Adjusting to the Drawdown, Report of the Defense Conversion Commission, Berteau, et al, United States Department of Defense, December 1992.

Economic Effects of Reduced Defense Spending, Congressional Budget Office Study, February 1992. 
$8 / 24 / 44$ 1t: $12 \mathrm{PM}$

Figure 1: U.S. Unemployment Rate and Share of Defense in GNP

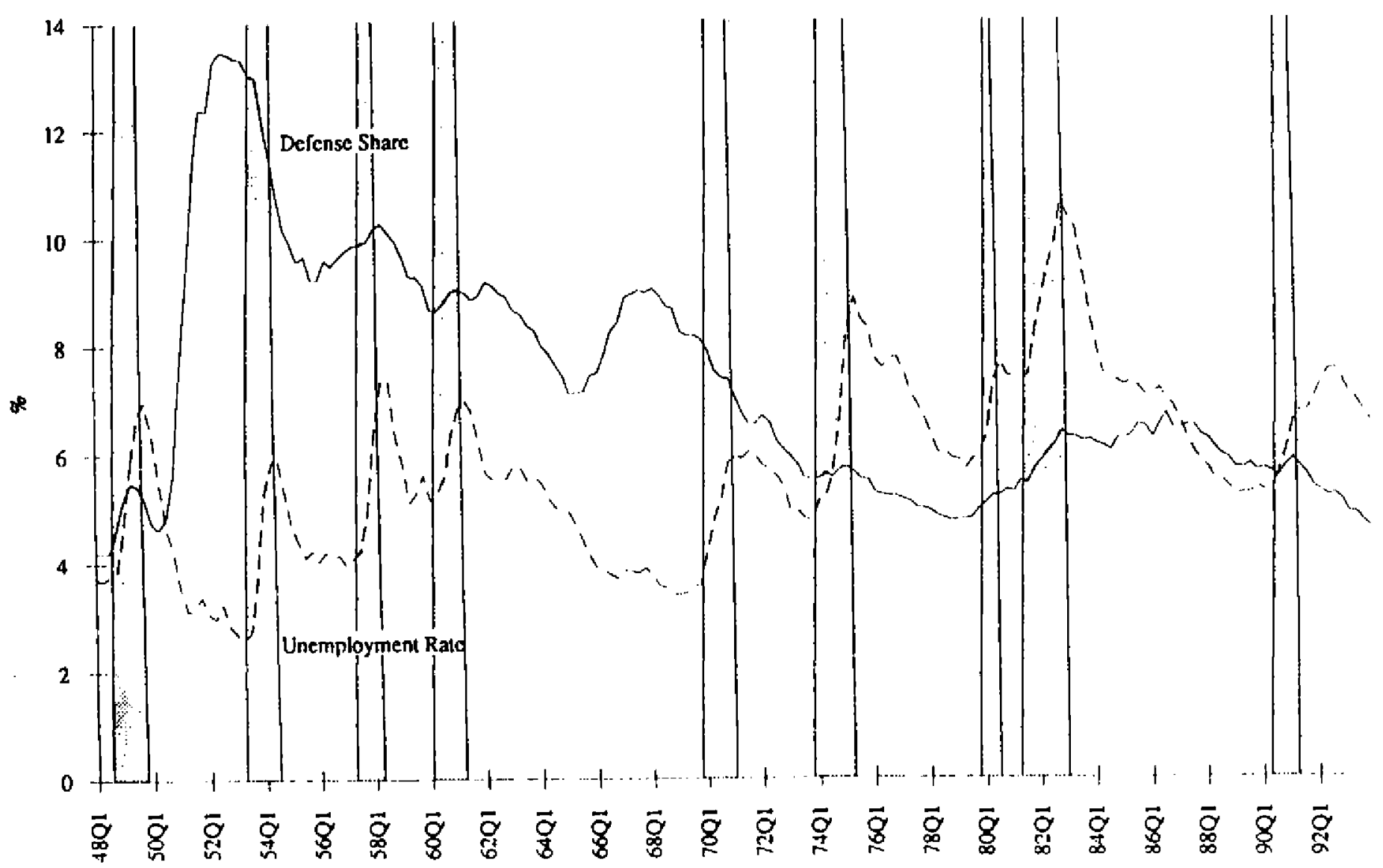


8/24/24 10:46 PM

Figure 2: Average Procurement Spending by Stale

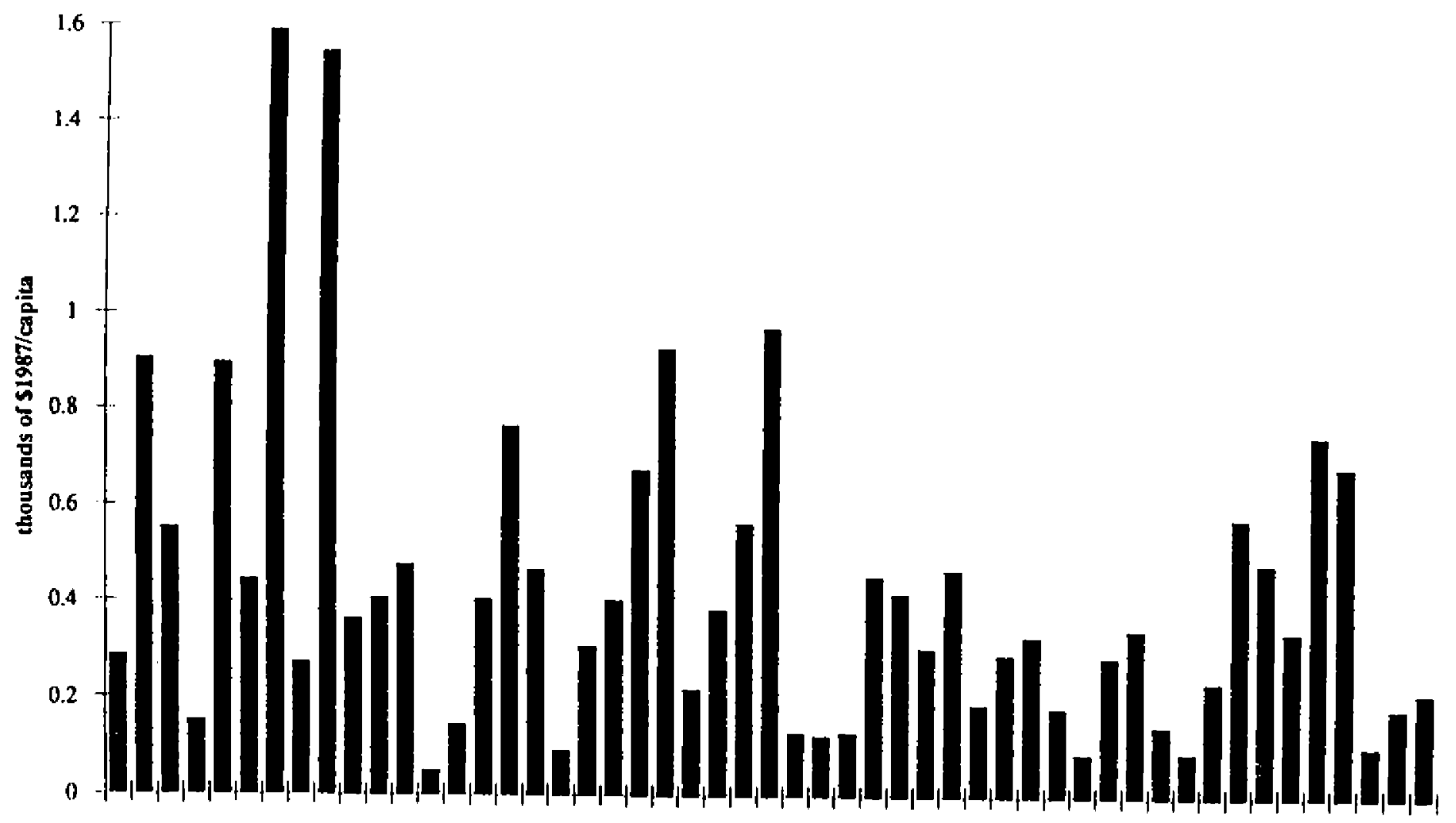

A A A ACCCD DF GII I I IKKLMMMMMMMMNNN NNNNNOOOPRSSTTUVYWWWW LK Z. KA OTECLAI DLNASYAEDAINSOTEVHJMYCDHKRAICDNXTTAAVIY 
8/44/4 i 1:19 PM

Figure 3: Procurement Spending in Several Slates

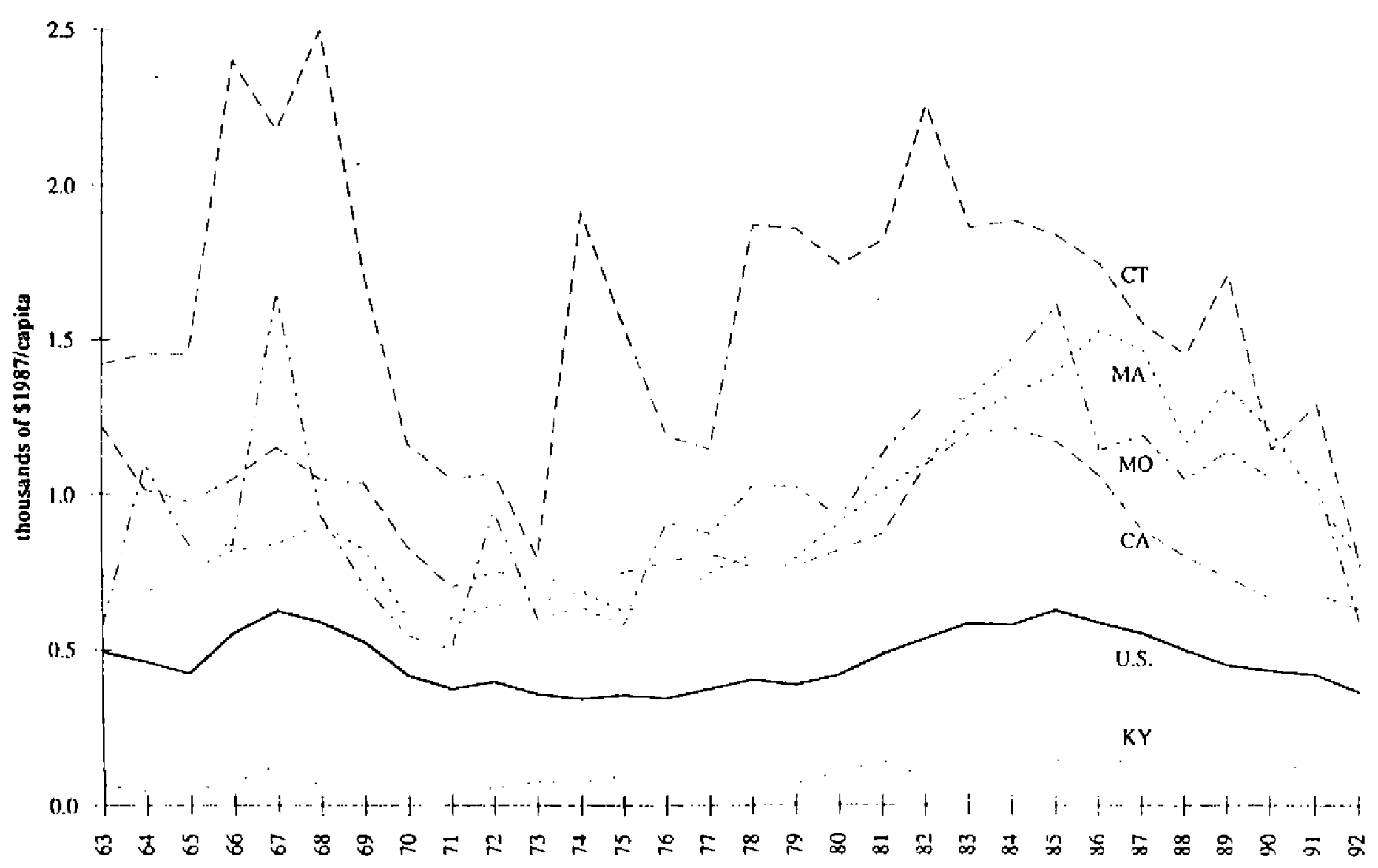




\section{Figure 4a: Impact of MIL, size Quintile 1}

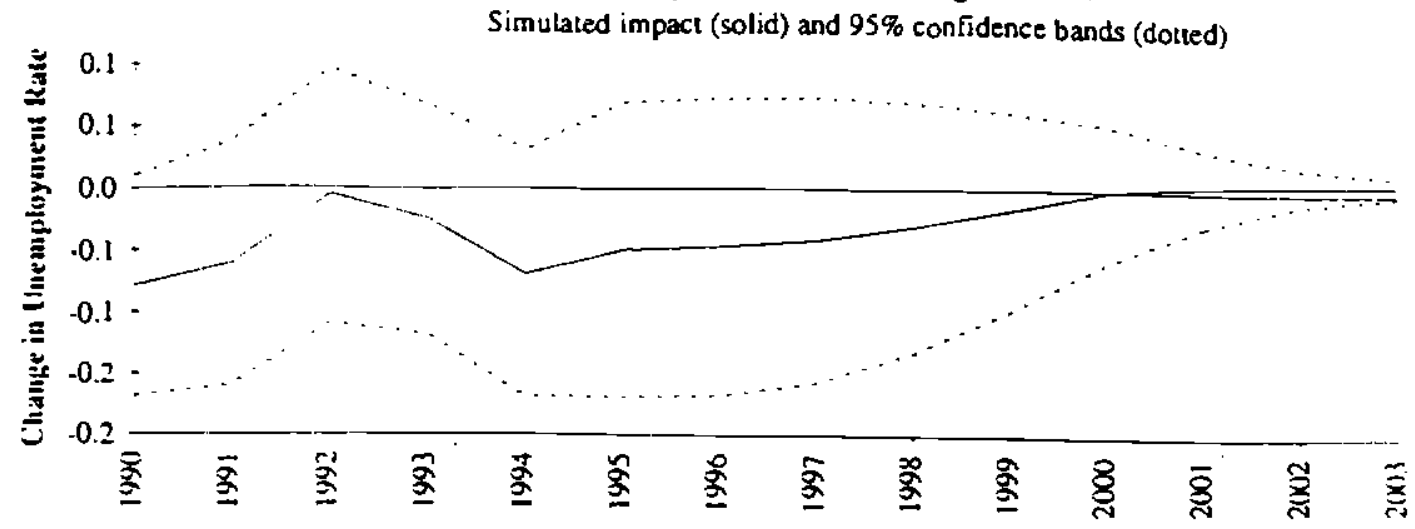

Figure 4b: Impact of MIL, size Quintile 2

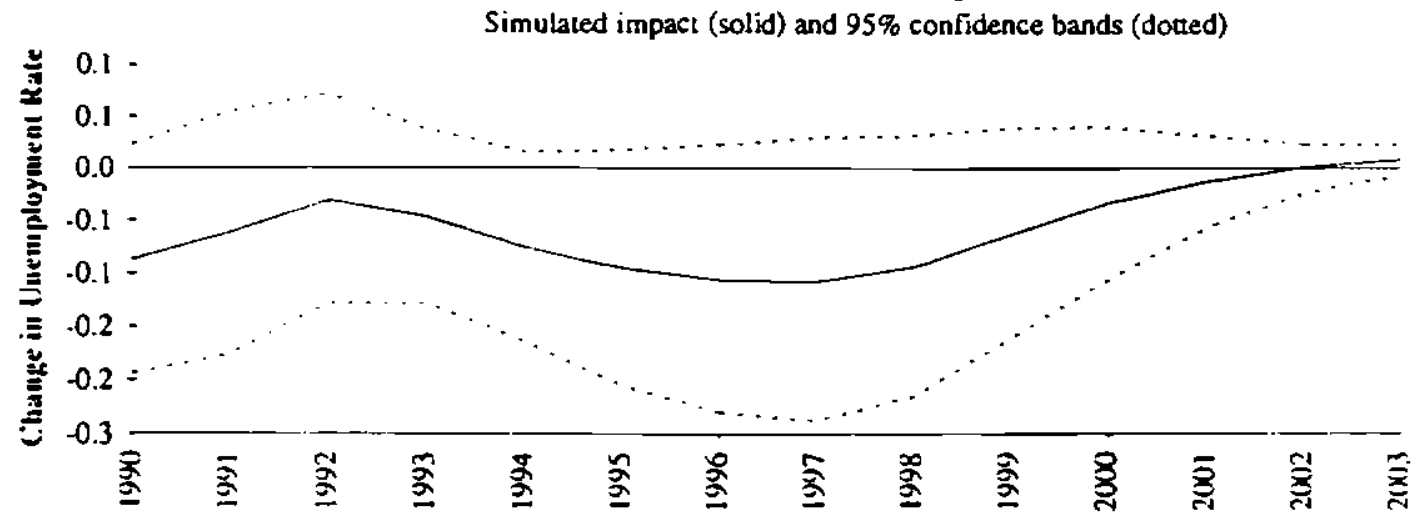

Figure 4c: Impact of ML, size Quintile 3

Simulated impact (solid) and $95 \%$ conlidence bands (dotted)

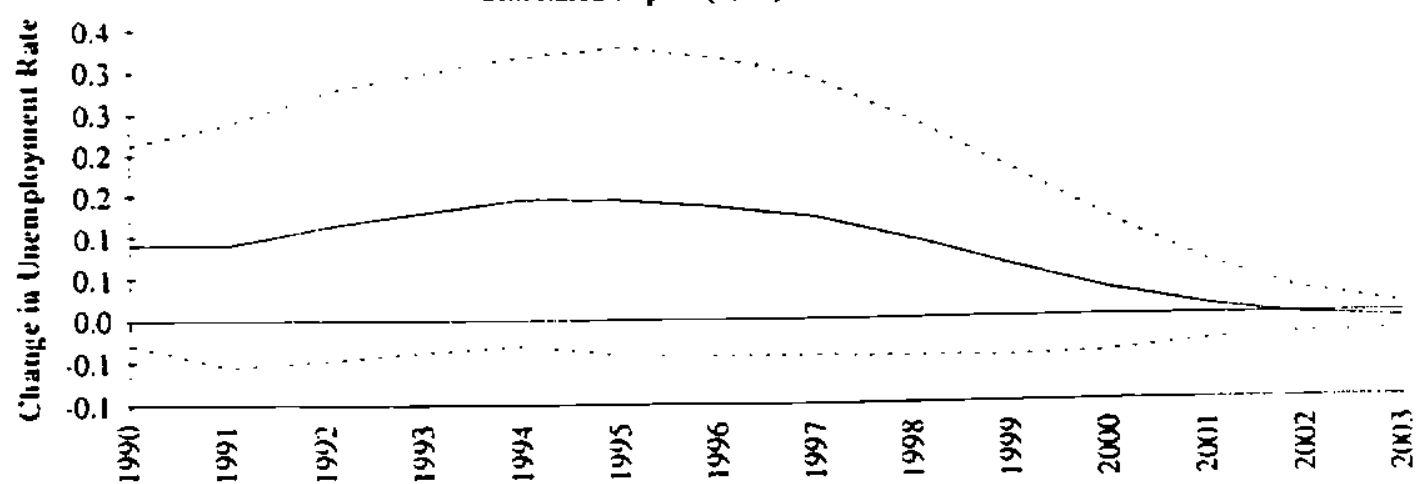


Figure 4d: Impact of MIL, size Quintile 4

Simulated impact (solid) and 95\% confidence bands (douted)

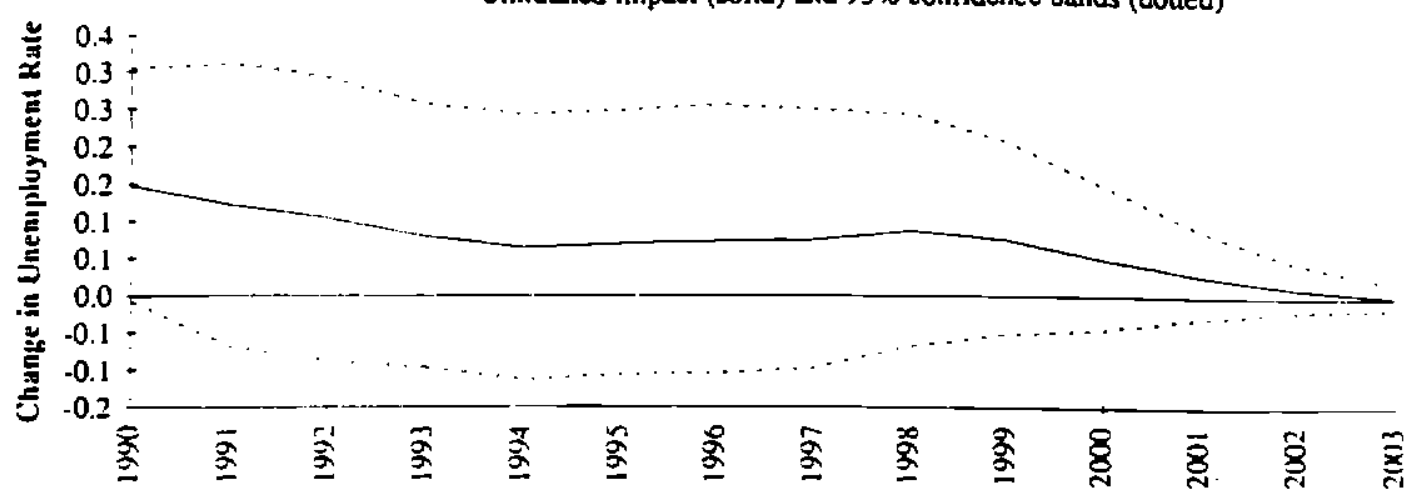

Figure te: Impact of MIL, size Quintile 5

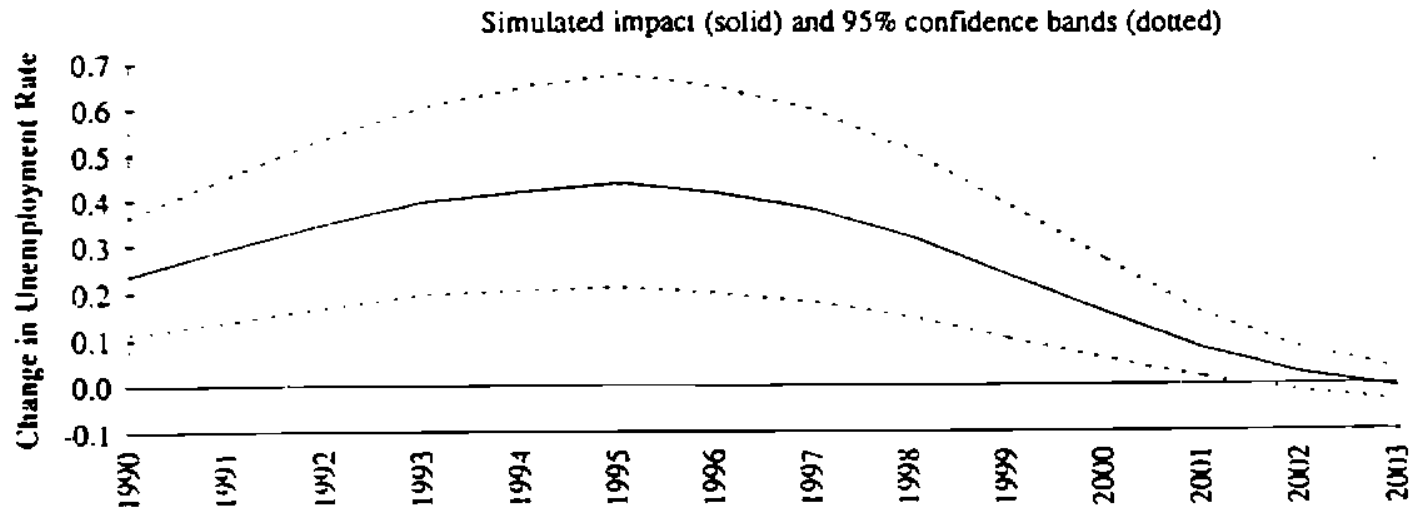


8/24/94 |6: 36 I'M

Figure 5: U.S. Unemployment Rate Impact of the Current Drawdown

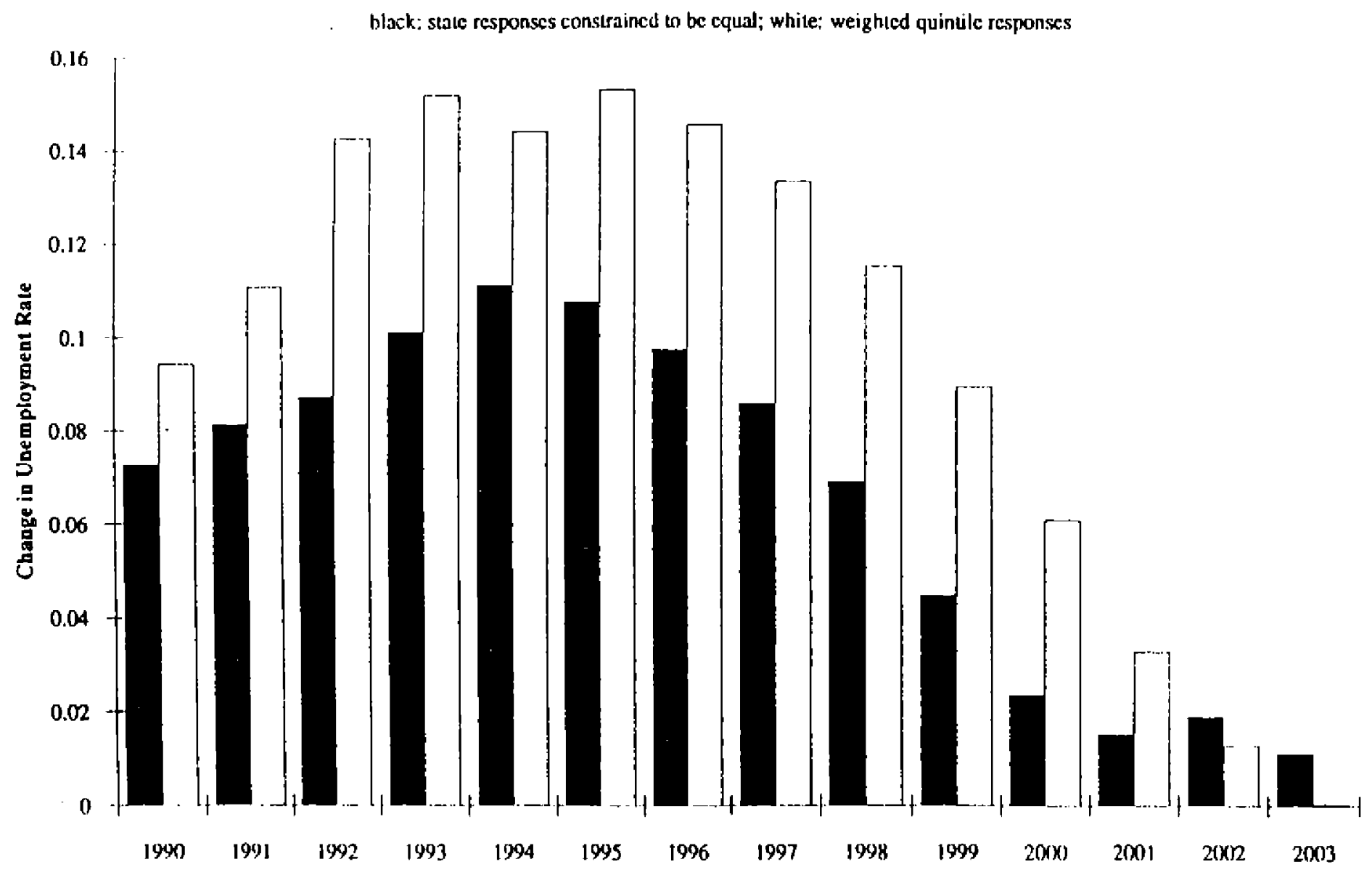


Table 1: Equation $U_{i t}=\Lambda_{i}+\theta_{t}+\alpha_{i} \mathrm{HBK}_{i t}+\sum_{m=1}^{4} \rho_{m} U_{i t-m}+\sum_{j=0}^{4} \beta_{j} M I L_{i t-j}$

\begin{tabular}{|c|c|c|c|c|c|c|c|}
\hline & $\Lambda_{i}$ & & $R_{i}^{2}$ & & $\Lambda_{i}$ & & $R_{i}^{2}$ \\
\hline $\begin{array}{l}A L \\
A K \\
A Z \\
A R \\
C A \\
C O \\
C T \\
D E \\
D C \\
F L\end{array}$ & $\begin{array}{l}2.05 \\
2.44 \\
1.67 \\
1.83 \\
1.93 \\
1.27 \\
1.39 \\
1.46 \\
1.99 \\
1.63\end{array}$ & $\begin{array}{l}(7.89) \\
(8.69) \\
(6.78) \\
(7.25) \\
(7.57) \\
(5.39) \\
(5.77) \\
(6.02) \\
(7.89) \\
(6.72)\end{array}$ & $\begin{array}{l}0.91 \\
0.01 \\
0.76 \\
0.88 \\
0.88 \\
0.78 \\
0.77 \\
0.87 \\
0.84 \\
0.90\end{array}$ & $\begin{array}{l}\mathrm{MT} \\
\mathrm{NE} \\
\mathrm{NV} \\
\mathrm{NH} \\
\mathrm{NJ} \\
\mathrm{NM} \\
\mathrm{NY} \\
\mathrm{NC} \\
\mathrm{ND} \\
\mathrm{OH}\end{array}$ & $\begin{array}{l}1.57 \\
0.60 \\
1.61 \\
0.89 \\
1.52 \\
1.86 \\
1.69 \\
1.13 \\
1.01 \\
1.85\end{array}$ & $\begin{array}{l}(6.35) \\
(2.55) \\
(6.26) \\
(3.54) \\
(5.69) \\
(6.69) \\
(6.26) \\
(4.39) \\
(4.02) \\
(6.72)\end{array}$ & $\begin{array}{l}0.80 \\
0.82 \\
0.83 \\
0.84 \\
0.89 \\
0.81 \\
0.88 \\
0.90 \\
0.04 \\
0.94\end{array}$ \\
\hline $\begin{array}{l}\text { GA } \\
\text { HI } \\
\text { ID } \\
\text { IL } \\
\mathbb{N} \\
\text { LA } \\
\text { KS } \\
\text { KY } \\
\text { LA } \\
\text { ME }\end{array}$ & $\begin{array}{l}1.39 \\
1.31 \\
1.60 \\
1.74 \\
1.68 \\
1.04 \\
0.88 \\
1.75 \\
2.22 \\
1.68\end{array}$ & $\begin{array}{l}(5.82) \\
(5.47) \\
(6.50) \\
(7.02) \\
(6.80) \\
(4.50) \\
(3.84) \\
(7.00) \\
(8.30) \\
(6.75)\end{array}$ & $\begin{array}{l}0.85 \\
0.64 \\
0.87 \\
0.95 \\
0.92 \\
0.92 \\
0.69 \\
0.89 \\
0.82 \\
0.82\end{array}$ & $\begin{array}{l}\text { OK } \\
\text { OR } \\
\text { PA } \\
\text { RI } \\
\text { SC } \\
\text { SD } \\
\text { TN } \\
\text { TX } \\
\text { UT } \\
\text { VT }\end{array}$ & $\begin{array}{l}1.24 \\
1.87 \\
1.79 \\
1.46 \\
1.47 \\
0.72 \\
1.67 \\
1.52 \\
1.19 \\
1.12\end{array}$ & $\begin{array}{l}(4.84) \\
(6.71) \\
(6.57) \\
(5.53) \\
(5.55) \\
(2.91) \\
(6.18) \\
(5.86) \\
(4.61) \\
(4.35)\end{array}$ & $\begin{array}{l}0.77 \\
0.90 \\
0.97 \\
0.77 \\
0.91 \\
0.48 \\
0.93 \\
0.85 \\
0.76 \\
0.89\end{array}$ \\
\hline $\begin{array}{l}\text { MD } \\
\text { MA } \\
\text { MI } \\
\text { MN } \\
\text { MS } \\
\text { MO }\end{array}$ & $\begin{array}{l}1.27 \\
1.58 \\
2.47 \\
1.14 \\
2.06 \\
1.40\end{array}$ & $\begin{array}{l}(5.38) \\
(6.51) \\
(9.02) \\
(4.88) \\
(7.95) \\
(5.84)\end{array}$ & $\begin{array}{l}0.87 \\
0.85 \\
0.86 \\
0.84 \\
0.91 \\
0.90\end{array}$ & $\begin{array}{l}\text { VA } \\
\text { WA } \\
\text { WV } \\
\text { WI } \\
\text { WY }\end{array}$ & $\begin{array}{l}1.23 \\
1.98 \\
2.87 \\
1.38 \\
1.22\end{array}$ & $\begin{array}{l}(4.78) \\
(6.99) \\
(9.48) \\
(5.27) \\
(4.78)\end{array}$ & $\begin{array}{l}0.82 \\
0.84 \\
0.90 \\
0.93 \\
0.74\end{array}$ \\
\hline
\end{tabular}

\begin{tabular}{|c|c|c|c|c|c|}
\hline $\begin{array}{l}\theta_{68} \\
\theta_{69}\end{array}$ & $\begin{array}{l}-0.29 \\
-0.44\end{array}$ & $\begin{array}{l}(-1.90) \\
(-2.79)\end{array}$ & $\theta_{g_{1}}$ & $\begin{array}{l}0.99 \\
2.59\end{array}$ & $\begin{array}{r}(4.90) \\
(1275)\end{array}$ \\
\hline$\theta_{0}$ & 0.81 & $(4.50)$ & $\theta_{83}$ & 1.04 & (4.73) \\
\hline$\theta_{1}$ & 0.46 & (2.55) & $\theta_{84}$ & -0.72 & $(-3.26)$ \\
\hline$\theta_{12}$ & -0.41 & $(-2.23)$ & $\theta_{85}$ & 0.96 & $(4.43)$ \\
\hline$\theta_{3}$ & -0.56 & $(-3.05)$ & $\theta_{86}$ & 0.93 & $(4.36)$ \\
\hline$\theta_{4}$ & -0.63 & (3.51) & $\theta_{87}$ & 0.22 & $(1.04)$ \\
\hline Ors & 2.66 & (14.75) & $\theta_{8 B}$ & -0.11 & $(-0.57)$ \\
\hline$\theta_{6}$ & -0.38 & $(-1.77)$ & $\theta_{89}$ & 0.13 & $(0.65)$ \\
\hline$\theta 7$ & 0.07 & $(0.33)$ & $\theta_{90}$ & 0.54 & $(2.79)$ \\
\hline$\theta_{8}$ & -0.29 & $(-1.40)$ & $\theta_{91}$ & 1.23 & (6.35) \\
\hline$\theta 9$ & 0.39 & $(1.96)$ & $\theta_{92}$ & 0.69 & (3.50) \\
\hline$\theta_{80}$ & 1.70 & (8.75) & & & \\
\hline$\beta_{0}$ & -0.39 & $(-2.21)$ & $\rho_{1}$ & 0.86 & $(29.70)$ \\
\hline$\beta_{1}$ & -0.20 & $(-1.07)$ & $\rho_{2}$ & 0.08 & $(-1.96)$ \\
\hline$\beta_{2}$ & 0.01 & $(0.07)$ & $\rho_{3}$ & 0.05 & $(-1.27)$ \\
\hline$\beta_{3}$ & -0.06 & $(-0.32)$ & $\rho_{4}$ & -0.06 & $(-2.15)$ \\
\hline$\beta_{4}$ & 0.19 & $(1.14)$ & & & \\
\hline
\end{tabular}

SSR $=685.98 ;$ SEE $=0.76, N=1326 . t$-statistics in parentheses. $R 2$ values use coefficients estimated on the whole sample and observations from the state. First year-dummy (1967) excluded for identificution. Handbook dummies $(\alpha s)$ not reported to save space. 
Table 2: Test for Whether MIL Enters in Differences

$$
\begin{aligned}
& \text { Equation } U_{i t}=\Lambda_{i}+\Theta_{t}+\alpha_{i} \mathrm{HBK}_{i t}+\sum_{m=1}^{4} \rho_{m} U_{i t-m}+\sum_{j=0}^{4} \gamma_{j} \Delta M I L_{i t \cdot j} \\
& \gamma_{0} \quad-0.26 \quad(-1.59) \\
& \begin{array}{llll}
\gamma_{1} & -0.37 & (-2.09)
\end{array} \\
& \gamma_{2} \quad-0.30 \quad(-1.74) \\
& \begin{array}{lll}
\gamma_{3} & -0.28 & (-1.82)
\end{array} \\
& \begin{array}{llll}
\Sigma \gamma & -1.29 & (-2.66)
\end{array}
\end{aligned}
$$

SSR $=688.20 ; \mathrm{SEE}=0.76, N=1326 . \quad F_{1,1190}$ for restriction that $\mathrm{MIL}$ enters in differences $=3.85 . \mathrm{p}$-value $=0.05$. 1-staristics in parentheses. First year-dummy (1967) excluded for identification. State, handbook, and year dummies are very similar to those in the unrestricted specification in Table 1 and thus not reported here. 
By average size of MIL:

Ouintile l: Idaho, Oregon, South Dakota, Kentucky, West Virginia, Nebraska, Montana, Nevada, Mlinois, South Carolina

Ouinple 2: Arkansas, Iowa, Oklahoma, Wisconsin, North Carolina, Wyoming, Michigan, Tennessee, Delaware, Alabama

Quinile 3: Pennsylvania, North Dakota, New Mexico, Louisiana, Ohio, Vermont, Rhode Island, Florida, Minnesota, Maine

Ouinile 4: Indiana, Georgia, New Jersey, Colorado, New Hampshire, Kansas, New York, Hawaii, Utah, Arizona

Ouintile 5: Mississippi, Texas, Maryland, Washington, Virginia, Califomia, Alaska, Massachusetts, Missouri, District of Columbia, Connecticut

By average size of MIL differences:

Quintile 1: Idaho, North Carolina, Kentucky, Nebraska, Oklahoma, Illinois, Oregon, South Carolina, New Mexico, Iowa

Quinile 2: Wisconsin, Pennsylvania, West Virginia, Alabama, Arkansas, Michigan, Nevada, New York, South Dakota, Tennessee

Quinile 3: Florida, Ohio, Minnesota, Indiana, Maryland, New Jersey, Califomia, Colorado, Rhode Island, Deleware

Quinile 4: Vermont, Georgia, Hawaii, Massachusetts, Arizona, New Hampshire, Texas, Utah, Kansas, Louisiana

Ouinile 5: Wyoming, Alaska, Maine, Montana, Washington, North Dakota, Virginia, Mississippi, Missouri, Connecticut, District of Columbia 
Table 4a: MII. Responses by Quintile of State Average $M I L$ Equation $U_{i l}=\Lambda_{i}+\theta_{i}+\alpha_{i} \mathrm{HBK}_{i l}+\sum_{m=1}^{4} \rho_{m} U_{i l-m}+\sum_{k=1}^{5} \sum_{j=0}^{3} \gamma_{j}^{k} \Delta M I L k_{i l-j}$

Coefficients on $\Delta M L^{k_{i r} . j:}$

Quintile

Lag

\begin{tabular}{ccccc}
$k=1$ & $k=2$ & $k=3$ & $k=4$ & $k=5$ \\
\hline 0.46 & 0.58 & -0.66 & 0.62 & -0.41 \\
$(0.69)$ & $(0.91)$ & $(-1.60)$ & $(1.32)$ & $(-2.03)$ \\
0.97 & 1.26 & -0.40 & -0.77 & -0.60 \\
$(1.37)$ & $(1.94)$ & $(-0.97)$ & $(-1.65)$ & $(-2.70)$ \\
0.66 & 0.18 & -0.30 & -0.58 & -0.41 \\
$(0.95)$ & $(0.29)$ & $(-0.75)$ & $(-1.28)$ & $(-1.87)$ \\
-0.78 & -0.11 & 0.02 & 0.07 & -0.40 \\
$(-1.28)$ & $(-0.22)$ & $(0.04)$ & $(0.15)$ & $(-1.96)$
\end{tabular}

$\Sigma \gamma$

$\begin{array}{ccccc}1.30 & 1.91 & -1.34 & -0.66 & -1.82 \\ (0.64) & (1.25) & (-1.28) & (-0.69) & (-3.13)\end{array}$

$\overline{\text { SSR }=674.38 \mathrm{SE}}=0.758 . N=1326$. i-statistics in parentheses.

Table 4b: MIL Responses by Quintile of State Average Change in $M I L$ Equation $U_{i l}=\Lambda_{i}+\theta_{i}+\alpha_{i} \mathrm{HBK}_{i l}+\sum_{m=1}^{4} \rho_{m} U_{i l-m}+\sum_{k=1}^{5} \sum_{j=0}^{3} \gamma_{j}^{k} \Delta M I L^{k_{i l, j}}$

Coefficients on $\Delta W L L^{k_{i l-j}}$ :

Ouintile

Lag

\begin{tabular}{ccccc}
\hline$k=1$ & $k=2$ & $k=3$ & $k=4$ & $k=5$ \\
\hline 1.45 & -0.10 & 0.50 & 0.00 & -0.33 \\
$(0.86)$ & $(-0.10)$ & $(0.83)$ & $(0.01)$ & $(-1.76)$ \\
0.82 & 1.64 & -0.79 & -0.72 & -0.32 \\
$(0.54)$ & $(1.77)$ & $(-1.39)$ & $(-1.90)$ & $(-1.48)$ \\
2.15 & -0.33 & -0.54 & -0.34 & -0.27 \\
$(1.38)$ & $(-0.36)$ & $(-0.93)$ & $(-0.89)$ & $(-1.30)$ \\
0.03 & -0.64 & -0.19 & -0.17 & -0.30 \\
$(0.02)$ & $(-0.74)$ & $(-0.35)$ & $(-0.45)$ & $(-1.65)$
\end{tabular}

$\sum \gamma$

$\begin{array}{ccccc}4.44 & 0.55 & -1.03 & -1.22 & -1.23 \\ (1.21) & (0.27) & (-0.86) & (-1.53) & (-2.12)\end{array}$

$\overline{S S R}=680.64 ;$ SEE $=0.761, N=1326$. i-statistics in parentheses. 
Table 5: MIL Responses by MII Quintile with Oil Price and Exchange Rate Controls Equation $U_{i t}=\theta_{t}+\Lambda_{i}+\alpha_{i} \mathrm{HBK}_{i t}+\sum_{m=1}^{4} \rho_{m} U_{i t-m}+\sum_{k=1}^{5} \sum_{j=0}^{j} \gamma_{j}^{k} \Delta M I L_{i t-j}+\phi_{i} \mathrm{OIL}_{i t}+\delta_{i} \mathrm{EXCH}_{i t}$

Coefficients on $\Delta M I L^{k}{ }_{i t-j}$ :

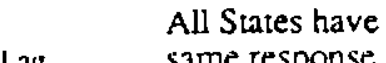

Las:

$j=0$

$j=1$

$j=2$

$j=3$

$\sum \gamma$

\begin{tabular}{lrr} 
& \multicolumn{1}{c}{ OIL } & \\
AL & 2.40 & $(2.50)$ \\
AK & -0.85 & $(-0.89)$ \\
AZ & 0.30 & $(0.32)$ \\
AR & 1.30 & $(1.35)$ \\
CA & -0.24 & $(-0.25)$ \\
CO & -0.02 & $(-0.02)$ \\
CT & -0.70 & $(-0.71)$ \\
DE & 0.73 & $(0.76)$ \\
DC & 1.16 & $(1.21)$ \\
FL & 0.26 & $(0.27)$ \\
GA & 0.36 & $(0.38)$ \\
HI & -0.80 & $(-0.83)$ \\
W & 0.66 & $(0.68)$ \\
I & 1.67 & $(1.75)$ \\
NN & 2.06 & $(2.15)$ \\
IA & 1.46 & $(1.52)$ \\
KS & -0.22 & $(-0.23)$ \\
KY & 1.52 & $(1.59)$ \\
LA & 0.04 & $(0.04)$ \\
ME & -0.06 & $(-0.06)$ \\
MD & 0.67 & $(0.70)$ \\
MA & -0.33 & $(-0.34)$ \\
MI & 2.39 & $(2.49)$ \\
MN & 0.41 & $(0.43)$ \\
MS & 1.49 & $(1.55)$ \\
MO & 1.39 & $(1.44)$
\end{tabular}

Quintile

\begin{tabular}{ccccc}
$k=1$ & $k=2$ & $k=3$ & $k=4$ & $k=5$ \\
\hline 0.27 & 0.36 & -0.53 & 1.03 & -0.28 \\
$(0.42)$ & $(0.55)$ & $(-1.25)$ & $(2.06)$ & $(-1.32)$ \\
0.83 & 1.53 & -0.51 & -0.27 & -0.45 \\
$(1.19)$ & $(2.23)$ & $(-1.21)$ & $(-0.54)$ & $(-1.83)$ \\
0.72 & 1.20 & -0.42 & -0.33 & -0.32 \\
$(1.04)$ & $(1.85)$ & $(-1.01)$ & $(-0.69)$ & $(-1.30)$ \\
-0.64 & 0.20 & -0.01 & 0.20 & -0.31 \\
$(-1.06)$ & $(0.40)$ & $(-0.03)$ & $(0.43)$ & $(-1.45)$ \\
1.19 & 3.29 & -1.47 & 0.63 & -1.37 \\
$(0.61)$ & $(2.02)$ & $(-1.37)$ & $(0.56)$ & $(-2.05)$
\end{tabular}

\section{EXCH}

$\underline{\text { OIL }}$

$-0.34$

$-0.34-(-1.47)$

$0.02 \quad(0.10) \quad \mathrm{NE}$

$-0.39 \quad(-1.67)$

$-0.34 \quad(-1.46)$

$-0.16 \quad(-0.71)$

$-0.32 \quad(-1.38)$

$-0.24 \quad(-1.03)$

$-0.43 \quad(-1.88)$

$-0.33 \quad(-1.44)$

$-0.42$

$(-1.83)$

\section{$-0.36$}

$-0.03 \quad(-0.13)$

$-0.18 \quad(-0.79)$
-0.32

$-0.32 \quad(-1.40)$

$-0.41 \quad(-1.77)$

$-0.13 \quad(-0.57)$

$\begin{array}{ll}-0.07 & (-0.31)\end{array}$

$-0.23 \quad(-1.02)$

$0.15 \quad(0.66)$

$-0.34 \quad(-1.47)$

MT
NE
NV
NH
NJ
NM
NY
NC
ND
OH
OK
OR
PA
RI
SC
SD
TN
TX
UT
VT
VA
WA
WV
WI
WY

0.14

(0.14)

$\mathrm{EXCH}$

$-0.52 \quad(-2.26)$

$-0.53 \quad(-2.29)$

$-0.46 \quad(-1.98)$

$-0.21 \quad(-0.89)$

$-0.20 \quad(-0.86)$

$-0.40 \quad(-1.74)$
1.07

$1.26 \quad(1.22)$

$0.88 \quad(0.86)$

$-0.03 \quad(-0.03)$

$0.37 \quad(0.36)$

1.59 (1.55)

$-1.59(-1.55)$

$2.44 \quad$ (2.38)

$-0.76 \quad(-0.74)$

$2.06 \quad(2.01)$

I.61 (1.57)

$1.88 \quad(1.83)$

$2.09 \quad(2.04)$

$\begin{array}{ll}-0.60 & (-0.58)\end{array}$

$-1.69 \quad(-1.65)$

$0.30 \quad(0.29)$
0.38

$0.38 \quad(0.37)$

$0.32 \quad(0.31)$

$0.80 \quad(0.78)$

$1.56 \quad$ (1.51)

$1.62 \quad(1.58)$

$-1.82(-1.76)$
$2.20 \quad(2.14)$
$-0.12 \quad(-0.52)$

$-0.22 \quad(-0.89)$

$-0.70 \quad(-2.97)$

$-0.57 \quad(-2.43)$

$-0.14 \quad(-0.61)$

$-0.41 \quad(-1.73)$

$-0.48 \quad(-2.04)$

$0.15 \quad(0.63)$

$-0.36 \quad(-1.52)$

$-0.02 \quad(-0.07)$

$-0.40 \quad(-1.71)$

$-0.36 \quad(-1.53)$

$\begin{array}{ll}-0.80 & (-3.40)\end{array}$

$-0.43 \quad(-1.84)$

$-0.02 \quad(-0.07)$

$-0.37 \quad(-1.57)$

$0.04 \quad(0.16)$

$-0.14 \quad(-0.58)$

$-0.44(-1.88)$

$-0.33 \quad(-1.40)$

$-0.11 \quad(-0.49)$

$-0.13 \quad(-0.56)$

$-0.24 \quad(-1.04)$

0.26 (1.11)

Notes: SSR $=575.88$ with quintiles; 589.00 with all states constrained to have same $\mathrm{MIL}$ response $\left(F_{16,1075}=\right.$ 1.53, p-value 0.06 ); $S E E=0.74 / 0.73 ; N=1326$. Oil price and exchange rate (foreign currency/\$) variables do not vary across states and are thus nomalized to Nebraska's response for identification. t-statistics in parentheses. 
Table 6: MII Responses by MII Quintile with Bartik, Oil Price and Exchange Rate Controls

$$
\text { Equation } \begin{aligned}
U_{i l}=\theta_{l}+\Lambda_{i}+\alpha_{i} \mathrm{HBK}_{i l}+\sum_{m=1}^{4} \rho_{m} U_{i l-m} & +\sum_{k=1}^{5} \sum_{j=0}^{3} \gamma_{j}^{k} \Delta M I L_{i t, j}^{k} \\
& +\phi_{i} \mathrm{OIL}_{i l}+\delta_{i} \mathrm{TWDL}_{i t}+\mu_{i} \mathrm{BRTK}_{i l}
\end{aligned}
$$

\begin{tabular}{|c|c|c|c|c|c|c|}
\hline \multirow[b]{2}{*}{ Lag } & \multirow{2}{*}{$\begin{array}{l}\text { All States have } \\
\text { same response }\end{array}$} & \multicolumn{5}{|c|}{ Ouintile } \\
\hline & & $k=1$ & $k=2$ & $k=3$ & $k=4$ & $k=5$ \\
\hline$j=0$ & $\begin{array}{l}-0.03 \\
(-0.15)\end{array}$ & $\begin{array}{c}0.59 \\
(0.45)\end{array}$ & $\begin{array}{c}0.43 \\
(0.62)\end{array}$ & $\begin{array}{c}-0.25 \\
(-0.55)\end{array}$ & $\begin{array}{l}1.25 \\
(2.38)\end{array}$ & $\begin{array}{l}-0.26 \\
(-1.15)\end{array}$ \\
\hline$j=1$ & $\begin{array}{c}-0.14 \\
(-0.67)\end{array}$ & $\begin{array}{l}0.51 \\
(0.56)\end{array}$ & $\begin{array}{c}1.58 \\
(2.17)\end{array}$ & $\begin{array}{c}0.61 \\
(1.23)\end{array}$ & $\begin{array}{c}-0.05 \\
(-0.10)\end{array}$ & $\begin{array}{r}-0.56 \\
(-2.23)\end{array}$ \\
\hline$j=2$ & $\begin{array}{c}-0.14 \\
(-0.69)\end{array}$ & $\begin{array}{c}0.55 \\
(0.62)\end{array}$ & $\begin{array}{r}0.69 \\
(0.87)\end{array}$ & $\begin{array}{c}0.80 \\
(1.61)\end{array}$ & $\begin{array}{c}-0.49 \\
(-0.93)\end{array}$ & $\begin{array}{c}-0.41 \\
(-1.63)\end{array}$ \\
\hline$j=3$ & $\begin{array}{c}-0.29 \\
(-1.63)\end{array}$ & $\begin{array}{c}-0.17 \\
(-0.26)\end{array}$ & $\begin{array}{c}-0.22 \\
(-0.33)\end{array}$ & $\begin{array}{c}0.20 \\
(0.45)\end{array}$ & $\begin{array}{c}-0.27 \\
(-0.50)\end{array}$ & $\begin{array}{r}-0.40 \\
(-1.80)\end{array}$ \\
\hline$\Sigma \gamma$ & $\begin{array}{l}-0.60 \\
(-2.00)\end{array}$ & $\begin{array}{c}1.49 \\
(0.24)\end{array}$ & $\begin{array}{c}2.47 \\
(0.64)\end{array}$ & $\begin{array}{l}1.36 \\
(0.77)\end{array}$ & $\begin{array}{c}0.43 \\
(0.32)\end{array}$ & $\begin{array}{c}-1.64 \\
(-3.11)\end{array}$ \\
\hline
\end{tabular}

A. Coefficients on $\Delta M I L^{k}{ }_{i i . j}$, Oil and Exchange Rates Excluded

Notes: $S S R=434.14$ with quintiles: 445.83 with all states constrained to have same $M$ IIL response $\left(F_{16,851}=1.43\right.$, p-value 0.11 ): $S E E=0.714 / 0.717 ; \mathrm{N}=1020$. Oil price and exchange rate (foreign currency/S) variables do not vary across states and are thus normalized to Nebraska's response for identification. - -statistics in parentheses.

\begin{tabular}{|c|c|c|c|c|c|c|}
\hline \multirow[b]{2}{*}{$\operatorname{Lag}$} & \multirow{2}{*}{$\begin{array}{l}\text { All States have } \\
\text { same response }\end{array}$} & \multicolumn{5}{|c|}{ Ouintile } \\
\hline & & $k=1$ & $k=2$ & $k=3$ & $k=4$ & $k=5$ \\
\hline$j=0$ & $\begin{array}{c}0.13 \\
(0.63)\end{array}$ & $\begin{array}{c}0.32 \\
(0.45)\end{array}$ & $\begin{array}{c}0.15 \\
(0.20)\end{array}$ & $\begin{array}{c}-0.09 \\
(-0.17)\end{array}$ & $\begin{array}{c}1.98 \\
(3.26)\end{array}$ & $\begin{array}{c}-0.20 \\
(-0.77)\end{array}$ \\
\hline$j=1$ & $\begin{array}{c}0.00 \\
(0.02)\end{array}$ & $\begin{array}{c}0.17 \\
(0.18)\end{array}$ & $\begin{array}{c}1.62 \\
(1.96)\end{array}$ & $\begin{array}{c}0.42 \\
(0.72)\end{array}$ & $\begin{array}{l}0.67 \\
(1.05)\end{array}$ & $\begin{array}{l}-0.50 \\
(-1.61)\end{array}$ \\
\hline$j=2$ & $\begin{array}{c}-0.05 \\
(-0.22)\end{array}$ & $\begin{array}{c}0.32 \\
(0.35)\end{array}$ & $\begin{array}{c}1.39 \\
(1.49)\end{array}$ & $\begin{array}{c}0.56 \\
(0.97)\end{array}$ & $\begin{array}{c}-0.19 \\
(-0.32)\end{array}$ & $\begin{array}{c}-0.45 \\
(-1.44)\end{array}$ \\
\hline$j=3$ & $\begin{array}{c}-0.21 \\
(-1.05)\end{array}$ & $\begin{array}{c}-0.16 \\
(-0.24)\end{array}$ & $\begin{array}{c}0.19 \\
(0.26)\end{array}$ & $\begin{array}{c}0.11 \\
(0.24)\end{array}$ & $\begin{array}{c}-0.12 \\
(-0.22)\end{array}$ & $\begin{array}{c}-0.41 \\
(-1.62)\end{array}$ \\
\hline$\Sigma \gamma$ & $\begin{array}{c}-0.13 \\
(-0.19)\end{array}$ & $\begin{array}{c}0.66 \\
(0.10)\end{array}$ & $\begin{array}{c}3.35 \\
(0.60)\end{array}$ & $\begin{array}{c}1.00 \\
(0.39)\end{array}$ & $\begin{array}{c}2.33 \\
(0.94)\end{array}$ & $\begin{array}{c}-1.55 \\
(-1.95)\end{array}$ \\
\hline
\end{tabular}

B. Coefficients on $\Delta M L^{k}{ }_{i l-j}$, Oil and Exchange Rates Included

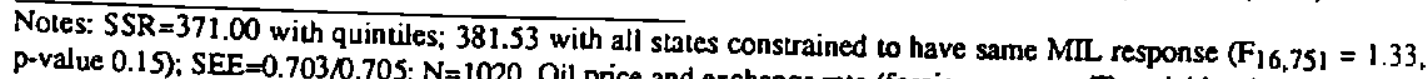
p-value 0.15 ); $S E E=0.703 / 0.705 ; N=1020$. Oil price and exchange rate (foreign cumency/S) variables do not vary across states and are thus nomalized to Nebraska's response for identification. 2 -statistics in parentheses. 